\title{
A barbárie da ignorância e a ética da vigilância crítica na cultura pós-moderna e na ficção de Mário de Carvalho ${ }^{1}$
}

José Cândido de Oliveira Martins (Universidade Católica Portuguesa)

Recebido em 31 ago. 2013/Aprovado em 23 abr. 2014

\section{Resumo}

A ficção do escritor português contemporâneo Mário de Carvalho fixa-se justamente no tópico da ruína ou barbárie cultural, como sintoma preocupante de uma cultura pós-moderna. Essa ignorância crescente de matrizes culturais insubstituíveis não é uma manifestação de neoconservadorismo, mas antes uma evidente preocupação ética do escritor e intelectual perante uma das faces da preocupante barbárie cultural dos tempos contemporâneos. Isso é particularmente evidente em algumas das suas narrativas, problematizando assim, indirectamente, a função ou natureza empenhada da arte literária, postura secundada por vários pensadores contemporâneos - de Theodor Adorno e Edward Said até George Steiner ou Peter Sloterdijk.

Palavras-chave: barbárie da ignorância; ética intelectual; Mário de Carvalho; memória cultural; pós-modernismo.

1 Artigo desenvolvido no âmbito do PEst-OE/FIL/UI0683/2014, Projeto Estratégico do Centro de Estudos Filosóficos e Humanísticos (CEFH), financiado pela Fundação para a Ciência e Tecnologia (FCT). 


\section{Barbárie da ignorância}

A já longa obra de ficção narrativa do escritor português Mário de Carvalho (Lisboa, 1944) é atravessada por temas mais ou menos obsessivos. Uma dessas ideias-chave é a da preocupação com o papel da educação ou da cultura, concebida como insubstituível matriz civilizacional e factor de identidade de um país e sobretudo de um civilização. Várias vozes narrativas e personagens das suas histórias realçam ou protagonizam o trágico (e o ridículo) de uma crassa ignorância cultural que se abate sobre a sociedade como uma epidemia incontrolável. Por exemplo, a ausência de referências culturais básicas ou o mau uso das estruturas fundamentais de uma língua põem em causa a própria comunicação, desde o intercâmbio linguístico quotidiano até à fruição da criação artístico-literária.

Nesta globalizada e relativizadora babel cultural, geram-se fenómenos de ruído comunicacional, de manifestações de kitsch ou ainda de indiferenciação entre arte e não arte, a que é preciso resistir criticamente. Ora, a concepção de ser humano e de uma multissecular tradição humanista, tal como os conhecemos hoje, foram profundamente moldadas por uma cultura com um passado multissecular. Pode o ser humano continuar a ser o mesmo, enformado por outras matrizes civilizacionais e tecnológicas, muito diferentes das que agora parecem estar em crise irremediável, numa cultura não logocêntrica, pelo menos no sentido tradicional?

Para este ficcionista, Mário de Carvalho, é imperioso mostrar - de várias formas, sobretudo recorrendo à provocação da ironia e à acutilância do humor ou ao jogo da paródia - que somos herdeiros de uma longa e rica tradição cultural, ameaçada e cercada por uma inculta barbárie contemporânea, que alastra de forma imparável pela aldeia global. Cioso da função e legitimidade da arte, à palavra literária não caberia apresentar soluções de política cultural e educativa; mas sim ser uma forma de aguda consciência crítica, de questionamento radical sobre o rumo civilizacional e sobre o lugar da própria palavra literária. Neste sentido, perante o desastre, os sintomas de pós-humanismo ou de crime de lesa-cultura, este autor subscreveria o pensamento de Adorno:

(...) desbarbarizar tornou-se a questão mais urgente da educação hoje em dia. O problema que se impõe nesta medida é saber se por meio da educação pode-se transformar algo de decisivo em relação à barbárie. [...] Considero tão urgente impedir isto (o perigo de que toda esta civilização venha a explodir pela barbárie). (ADORNO, 1996, p. 155)

Este aspecto suscita-nos uma reflexão contextualizadora, que comprove como este tema é recorrente numa certa tradição crítica contemporânea, ao conferir à arte e à literatura uma ampla funcionalidade, nomeadamente na complexa sociedade contem- 
2 Cf. George Steiner (2004, p. 47), em Barbárie da ignorância. Já Friederich Nietzsche (1992), defendia que, desde o mundo grego, o devir da civilização se esforça por congregar duas forças contraditórias: os instintos bestiais e os impulsos civilizados, simbolicamente representados em Dionísio e Apolo. Por outras palavras, a civilização ou a cultura têm subjacente a "barbárie" como tendência autodestrutiva; ou seja, assenta nesta duplicidade de forças dionisíacas e apolíneas, procurando equilibrar - de forma muitas vezes difícil e precária - a violência, desmesura e a embriaguez do dionisíaco com o equilíbrio, medida e a luz do apolíneo. Neste sentido, o pathos do medonho e do bárbaro não é elemento estranho a uma dada cultura (como a grega), que venha necessariamente de fora, mas mostra-se endógeno ou ontológico, é inerente à sua própria natureza. Cabe à criação cultural (tragédia, por ex.) operar a superação desta dicotomia entre "barbárie" e "civilização". porânea, tão assiduamente caraterizada como l'âge des extremes (E. Hobsbawm), atravessada por acentuadas rupturas espirituais e civilizacionais, abalando narrativas ideológicas, certezas ou limites estabelecidos Por outras palavras, é uma época perturbada por uma iconoclasta desconstrução - singular forma de hybris, com a marca do pensamento pós-moderno - de normas, valores e códigos, sejam eles estéticos, culturais ou sociais, numa contínua crise de legitimação (Habermas). O ponto que nos importa focar é apenas este: como é que a palavra literária de um escritor de hoje reage perante o espetáculo do extremo representado por uma diagnosticada barbárie cultural da sociedade actual.

Como sugerido, na sua amplitude semântica de anormalidade, o extremo contemporâneo pode ser entendido de várias formas, uma vez que, à imagem do Proteu da mitologia, comporta vários rostos. Num texto intitulado $O$ direito à literatura, Antônio Candido (2004, p. 12) mostra-se peremptório ao afirmar que, malgrado todos os progressos verificados nas sociedades modernas e contemporâneas, "a barbárie continuou impávida entre os homens. Todos sabemos que a nossa época é profundamente bárbara, embora se trata de uma barbárie ligada ao máximo de civilização". Ou seja, ao contrário do que previam certas visões utópicas da filosofia da história e do humanismo sobre os benefícios do progresso e do advento da plena felicidade humana, a barbárie cresce a par do desenvolvimento civilizacional. Como relembra uma personagem de Mário de Carvalho, o processo de ascensão cultural do ser humano não é garantido, nem sempre progressivo. (cf. CARVALHO, 2003, p. 173)

Ora, como referido, uma das faces do extremo contemporâneo é a erosão da memória cultural e a correlacionada aceitação de uma forma singular de barbárie - a incultura ou ignorância geral, da tradição, da história, da identidade. Entende-se aqui barbárie como regressão a um certo primitivismo (selvajaria e ignorância, recuo a estádios civilizacionais anteriores ou pré-civilizacionais); o mesmo é dizer, decomposição ou destruição de um riquíssimo e multissecular património cultural.

Há algumas décadas, na cultura pós-Auschwitz, e perante os perigos da barbarização, o citado Adorno enfatizava reiteradamente o papel fundamental da formação (Bildung) ou da educação, como forma de impedir ou pelo menos de minorar a barbárie ou atraso cultural dos cidadãos, contrariando assim um latente "impulso de destruição" (noção freudiana presente no pensamento de Adorno²) no estado contemporâneo da civilização, contribuindo assim para a formação e emancipação do cidadão e, em última instância, para a sobrevivência humana:

Entendo por barbárie algo muito simples, ou seja, que, estando na civilização do mais alto desenvolvimento tecnológico, as pessoas se encontrem atrasadas de um modo particularmente disforme em relação a sua própria civilização - e não apenas 
por não terem (...) experimentado a formação nos termos correspondentes ao conceito de civilização, mas também por se encontrarem tomadas por uma agressividade primitiva, um ódio primitivo ou, na terminologia culta, por um impulso de destruição (...) (ADORNO, 1996, p. 155)

Mais próximo de nós, também George Steiner tem caracterizado alguns dos mais preocupantes sintomas da barbárie da ignorância cultural que atinge o Ocidente, como um dos problemas mais ameaçadores do nosso tempo, sob a forma de profunda ruptura civilizacional - fim radical de uma cultura e tradição? $\mathrm{Ou}$ mutação radical? A aculturação e a crescente hegemonia de outros discursos socialmente dominantes conduziu o legado humanista a uma marginalização progressiva; mas mais relevante ainda, para o ensaísta inglês, a cultura mostrou-se ineficaz para travar as mais terríveis atrocidades do séc. XX.

Discordando da apologia da alta cultura, sustentada por um T. S. Eliot, em Notes towards the Definition of Culture [1948], e desmistificando assim a velha utopia humanista desde o ensaio No Castelo do Barba Azul [1971], para Steiner (1992, p. 40), a barbárie das grandes guerras do séc. XX demonstrou à saciedade que o humanismo e a cultura não impediram o ser humano desses extremos de bestialidade, de uma feritas pulsional: "Mas o certo é que a barbárie que sofremos reflecte, em numerosos pontos precisos, a cultura de onde brotou e quis profanar". Quando questiona o pretenso elitismo do legado humanista, no seio de uma pós-cultura ou contra-cultura, interroga-se Steiner (1992, p. 92) de modo indisfarçavelmente cético: "Que bem trouxe a tradição humanista às massas oprimidas da comunidade? De que se serviu ela quando a barbárie se fez anunciar? Que poema imortal jamais deteve ou moderou o terror político - enquanto foram muitos os poemas que o celebram?". À cultura humanista há que assacar muitas vezes os pecados da cumplicidade, da fragilidade ou simplesmente da impotência. A resposta a essas dúvidas angustiantes é dada especialmente em Barbárie da ignorância, o título que nos inspirou para este texto, em registo directo de entrevista:

porque é que as humanidades, no sentido mais amplo da palavra, porque é que a razão das ciências, não nos deram qualquer protecção frente ao inumano? (...) porque é que efectivamente se pode tocar Schubert ao serão para, de manhã, se voltar, no campo de concentração, ao cumprimento do dever? Nem a grande leitura, nem a música, nem a arte puderam impedir a barbárie total. E foram até, muitas vezes, um adorno dessa barbárie! (STEINER \& SPIRE, 2004, p. 43)

Constatação desenganada, como vemos, desmistificando frontalmente uma utopia multissecular, de uma modernidade não cumprida: a cultura humanista não terá passado muitas vezes de um adorno supérfluo e ineficaz perante as maiores manifestações 
da barbárie humana. Ora, é hoje mais ou menos consensual que, nesta época de "desmoronamento" e de "simulacros", a cultura pós-moderna tende a operar uma rasura da tradição, numa patológica amnésia. Isso é bem visível na vertigem dos media áudio-visuais e tecnológicos. Ao mesmo tempo, na lógica cultural do capitalismo tardio (Jameson), através do uso de técnicas diversas (da citação ao pastiche e à paródia), procede-se a à amálgama de estilos e níveis da cultura, de arte e da literatura - e tudo parece ter o mesmo estatuto (anything goes...), uma obra clássica da literatura ou um texto opinativo da imprensa; e mesmo o passado histórico surge numa rede de associações e simulacros, de modo frequentemente lúdico e rareficado, em múltiplas e tantas vezes iconoclastas formas de reescrita.

\section{2. Ética da vigilância crítica}

Neste quadro, que têm os escritores ou os intelectuais a ver com o rumo da sociedade ou da coisa pública? Menos céptico que Steiner, Said (2006, p. 167) debruçou-se particularmente sobre a figura e a função do "intelectual como vigia". Ao escritor e ao homem de cultura impõe-se hoje como no passado uma ética da vigilância crítica, que passa por uma concepção interventiva e prometaica da palavra, política, artística ou literária. Nem outro papel se esperava de uma arte herdeira do humanismo que, malgrado as evoluções de mundividência, moldou o ser humano ao longo de séculos.

Os sintomas da barbárie cultural quotidiana de uma sociedade podem ser muito variados, faltando aferir se são conjunturais ou se, mais grave, são considerados endémicos e difíceis de controlar. Como também nos devemos interrogar se o diagnóstico feito sobre uma dada sociedade não pode ser generalizado, por exemplo, ao espaço europeu ou mundial. Como ainda nos podemos questionar se certas formas de violência são ou não sintomas de uma diagnosticada barbárie cultural.

Ora, como afirmado, entre os autores contemporâneos de língua portuguesa que de mais detido e certeiro têm problematizado ficcionalmente este tema, destaca-se Mário de Carvalho. De maneira particular em alguns dos seus romances, este ficcionista denuncia, lúdica e criticamente (castigat ridendo mores) - através do registo da ironia, do género da sátira e da estratégia da paródia -, algumas das principais manifestações da extrema incultura dos tempos pós-modernos, que apenas poderemos enumerar e ilustrar muito rapidamente, na sua visão amarga e distópica, sem cairmos nós na tentação da ignoratio elenchi, falácia muito em voga. (cf. CARVALHO, 2010, p. 85)

Desde logo, densamente intertextual, a escrita deste autor denuncia, pela ironia e pela paródia, a ruptura ou quase apagamento das raízes da Antiguidade - desde as referências dos grandes clássicos literários aos fundadores do pensamento filosófico, como 
Platão, Aristóteles ou Horácio. Ora parafraseia livremente pensamentos da Poética aristotélica sobre a relevância do entrecho ou da ação; ora invoca ironicamente as musas (como Polímnia) para auxílio da obra que se vai construindo. (cf. CARVALHO, 2003b, p. 16 e 17 et passim)

A pretexto das inovações da sua escrita romanesca, desafia-se o leitor com pensamentos destes e de outros autores, e eles simplesmente não serão reconhecidos. E não se trata de "citações encapotadas", literatices ou de eruditas referências ao leitor; mas apenas considerações que deviam fazer parte da enciclopédia comum de leitores e cidadãos escolarizados (da filosofia e da literatura, da música e das artes, etc.). Também nesse sentido se devem ler algumas invocações mais ou menos frequentes ao "experiente leitor"; ou o piscar-de-olho de várias inscrições epigráficas e paratextuais que aparecem na escrita de Mário de Carvalho. No bosque da escrita ficcional, o leitor deveria possuir uma enciclopédia básica que lhe permitisse a cabal compreensão do legado dessa tradição literária, referências que num iluminado mapeamento permitissem navegar estética e culturalmente.

Correlacionadamente, o ficcionista afirma, de vários modos, a crescente erosão da memória cultural, nomeadamente estética e literária, das literaturas e culturas actuais, desde logo as europeias. É esta constatação que justifica a chocante falta de referências culturais das gerações mais jovens; ou a simples destruição de achados arqueológicos pelos mais velhos, quando incultos, por exemplo, na escavação da cratera para uma piscina (cf. CARVALHO, 2003b, p. 127, 130) - em tudo se demonstrando ignorância crassa e falta de mínima sensibilidade cultural.

Por isso, também já ninguém se surpreende também com a chocante ignorância linguística ou cultural dos cidadãos ou de profissionais da comunicação, como os jornalistas, sendo encarada como mais uma manifestação da presente ignorância do "nacional portuguesismo". Como é que os potenciais leitores contemporâneos, não tendo sequer bons hábitos de leitura, podem ficar esteticamente sensibilizados diante da "artesania da escrita" (cf. CARVALHO, 2003b, p. 209, 216), da teia de referências intertextuais ou da imaginação de certo escritor? Com seu potencial de criatividade e de reflexão, a língua literária actual é cada vez mais estranha às incultas turbas de bárbaros contemporâneos. Até para alguns aspirantes a intelectuais (como Bernardo Veloso, que "tinha lido três livros na vida"), a tradição literária é entediante: "Os restantes autores, desde Homero a Saramago, considerava-os dispensáveis por tediosos". Entre muitas outras manifestações de "envilecimento do país" (CARVALHO, 2003a, p. 83, 134) que abundam na escrita deste autor.

Neste quadro de ruína, um dos fenómenos mais significativos é o abastardamento da língua nacional, como meio insubstituível de comunicação quotidiana e de expressão estético-literária; 
mas também como símbolo identitário de uma nacionalidade, ou mesmo de um espaço multinacional (CPLP ou PAPLOP). Do ensino à comunicação social e às inter-relações diárias, a língua lusa é profundamente maltratada e diminuída nas suas potencialidades (lexicais, sintáticas e semânticas), reduzida a uma espécie de koiné elementar, cada vez mais próxima do nível rudimentar das mensagens rápidas dos sms e das redes sociais.

Neste contexto, os narradores de Mário de Carvalho assumem-se como provocantes "viajantes do vocabulário, da semântica e da real fantasia". (CARVALHO, 2003b, p. 19) No final de um longo e expressivo monólogo, proferido por quem se apresenta como símbolo de uma "nova cultura", Nelson, o filho do coronel Amílcar Lencastre e de Maria José, interpela os pais - "quem é que liga a isso da gramática?" (CARVALHO, 2003b, p. 75). E quem diz isto, fá-lo num "português lastimável" como o das suas namoradas ocasionais. Numa irresistível caricatura, um dos narradores sustenta mesmo que "Hoje, se rasoura, ou melhor, se nivela a língua pela riqueza lexical e vocabular de um certo Tarzan, Rei dos Macacos e da Selva". (CARVALHO, 2010, p. 43)

Ao mesmo tempo, consuma-se a estandardização do consumo cultural kitsch pelos fenómenos de massa (televisão, música popular, cinema, etc.), acompanhado pela popularização da produção emocional e comercial, entre outras formas de "terrorismo" cultural e de grassa ignorância. Esta forma de terrorismo cultural constitui um cerco que se abate sobre as sociedades contemporâneas, configurando-se como um dos rostos da ruína ou do extremo do nosso tempo pós-humanista. A própria música popular tradicional, na variedade e riqueza das suas manifestações, é abafada pelo fenómeno da música "pimba" (de uma vedeta como Soraia Marina), expressão musical popularucha, destituída de algum valor cultural ou estético, a par de outros "momentos culturais", como referido cinicamente na escrita de Mário de Carvalho. E no campo literário, misturam-se e confundem-se obras clássicas do passado e do presente com fenómenos de popularidade e de marketing, como os livros adocicados de Paulo Coelho ou as velhas histórias de Ponson du Terrail. (cf. CARVALHO, 2003a, p. 33; e 2010, p. 75) É o reino do vale tudo, depois da rasura da memória literária, refractária a qualquer estabelecimento de um cânone.

Ao mesmo nível, ocorrem as manifestações de violência gratuita, fora dos limites da legalidade ou da civilidade, incluindo impulsos destrutivos de todas as formas de autoridade, da ordem democrática vigente ou do património público, regredindo a formas primitivas de violência física ou de agressão gratuita, libertando os instintos bestiais de ser humano, fora da esperada racionalidade. Isso é visível, por exemplo, nos bandos de sujeitos que procedem a assaltos violentos; ou nos comportamentos bárbaros dos adeptos de futebol; e ainda em outras manifestações coletivas de clubes desportivos, partidos políticos, etc., entre outras 
exibições coletivas de "multidões javardas". (CARVALHO, 2003b, p. 107, 147)

Deste modo, o ambiente geral parece convidar à mais corrente má-educação ou à imaturidade de massas, ao facilitismo e à indolência, ao desenrascanço e à corrupção - das instituições públicas e do ensino, passando pelos caciques das autarquias locais, até à vida particular do mais comum cidadão -, perante a inércia cúmplice de todos. Aliás, no campo relevante da educação ou do ensino, assiste-se à demissão passiva do sistema educacional, cedendo à facilidade e aos mínimos padrões de exigência, fundamentados em pseudo-teorias pedagógicas, orientadas pelo "politicamente correto". Por vezes, só resta a confissão desalentada: “(...) era inútil discursar sobre as virtudes do saber (que aprendiam eles na escola, afinal?). (CARVALHO, 2003a, p. 37)

No domínio da vida quotidiana, não surpreende que se assista a um "país tagarela", dado à "pulsão coloquial" incontrolada e improdutiva; bem como à inflação do chico-espertismo descarado dos fura-vidas, com contornos pícaros, para não dizer trágicos, como na figura hilariante e caricata de Emanuel Elói em Fantasia para dois coronéis - protótipo do "atávico malandrim". Com a sua esperteza saloia, vão-se "safando" na vida ou sobrevivendo com expedientes impensáveis e portuguesíssimos... O mesmo clima de desresponsabilização e de imaturidade se estende àquele "jovem casal desavindo" de A arte de morrer longe, que enfrenta os problemas do casamento e a iminência do divórcio de forma leviana e infantilizada, espelhando a crise que também desagrega hoje os "afectos humanos", com consequências fatais nos laços familiares e sociais. (CARVALHO, 2010, p. 14 e 94)

O baixo nível educacional e cultural pode-se também aferir por comportamentos de convivência quotidiana - por exemplo, pela forma de conduzir ou de estacionar nas cidades (cf. CARVALHO, 2003a, p. 53); e ainda por outras atitudes que definem a "qualidade de vida" de um país e a postura dos seus cidadãos, como a patológica falta de pontualidade: "neste país ninguém chega a horas, diz-se que é um dos traços patentes da entranhada descidadania da lusitana gente". (CARVALHO, 2003a, p. 84) Para a voz crítica do narrador de Mário de Carvalho, estes e outros aspetos do retrato geral são relevantes e elucidativos. Além disso, "parte da nossa alma lusa consome-se nesta enervada previsão das contrariedades nacionais" (CARVALHO, 2003a, p. 122). Em outro romance, em jeito de libelo crítico, volta a denunciar-se o custo destas "contingências que moem e desesperam quem queira tratar de certos assuntos práticos em Portugal". (CARVALHO, 2010, p. 39)

O pior é que este fenómeno vasto já não é exclusivo da capital do país e de outros espaços urbanos; antes se alastra em contaminação imparável ao interior mais rural do país, como na aldeia de Grudemil, no baixo Alentejo. E isso acontece perante a impotência e a ignorância das entidades responsáveis, ou mesmo 
3 "Reino da estupiexpressão, de enorme ressonância na história da cultura portuguesa, nomeadamente desde a poesia do setecentista Francisco Melo Franco até ao acutilante ensaísmo de Jorge de Sena, perpassando uma visão amargamente crítica de um certo Portugal estagnado e retrógrado, afastado dos ventos da modernidade cultural.

4 Para além da paródica citação camoniana, descontextualizada para o cenário contemporâneo, sobressai em Mário de Carvalho o desejo simultâneo de interpretar o presente com a memória do passado, por um lado; mas, ao mesmo tempo, o intuito de rever certos traços culturais ou estereótipos tidos por configuradores da identidade portuguesa ou "portugalidade" (cf. CARVALHO, 2011, p. 276 et passim). diante da ociosidade e da apatia de todos. Numa palavra, perante a cúmplice indiferença, floresce o "reino da estupidez" e da barbárie na "Pátria lusitana". (CARVALHO, 2003b, p. 104)³ E uma das causas mais insistentemente apontadas para esta ignorância e desconcerto é a deficiência de uma política educacional séria, no mundo atual, como quando uma voz narrativa reflete: "Eis uma das consequências da péssima educação que se ministra na Europa hoje". (CARVALHO, 2010, p. 37)

Estamos assim perante a crescente catástrofe da massificação acrítica, que implica a homogeneização do homem contemporâneo - e a sua metamorfose numa outra concepção de homem? -, para usarmos uma ideia cara ao pensamento de autores como Paul Virilio e de Jean Baudrillard. E uma das facetas, além do estereotipado "pronto-a-pensar", é justamente o de uma "amnésia organizada" (cf. STEINER, 1992, p. 112), criminosamente iniciada no ensino básico ou obrigatório de vários sistemas educativos, sobretudo no diz respeito à cultura humanista (histórica, filosófica e literária), no âmbito de um crescente "recuo da palavra", face à ditadura da imagem e das novas tecnologias multimédia.

Neste quadro de ruptura, pode perguntar-se com Mário de Carvalho: é este tipo de ser humano que queremos formar hoje? Continuamos a testemunhar passivamente a inoperância dos atuais sistemas democráticos e a falência dos curricula educacionais? Estamos de acordo com o esvaziamento radical de uma ética básica, negação da ordem instituída num estado democrático ou profunda metamorfose civilizacional, em ordem à instituição de um novo contrato social? Enfim, não caberá ex professo ao universo ficcional de um escritor contemporâneo apresentar soluções de reforma político-cultural. Já é muito louvável que, através dos mundos possíveis da ficção, ele concorra para um certo diagnóstico e consciencialização crítica da realidade circundante. Mas uma coisa é certa: "Ainda cabe muita coisa a aperfeiçoar na nossa democracia..." (CARVALHO, 2003b, p. 50)

Porém, por mais compreensão que haja, perante deficiências e comportamentos endémicos, subsiste o desencanto diante do desapiedado retrato da sociedade portuguesa atual (talvez tragicamente semelhante a outras), do que só pode resultar um lamentoso eco de Camões, que culmina o explicit de uma narrativa: "Nô mais, ficção, nô mais! Desce tu, Musa, a de sorriso loução, ganha-me a benevolência dos meus concidadãos e diz-me: «Há emenda para este país?»". (CARVALHO, 2003b, p. 227) $)^{4}$ Enfim, os fenómenos de ruína cultural e de bárbara decadência são tão visíveis e entranhados que a voz narrativa não resiste a múltiplas paráfrases intertextuais como esta: "Nas nossas ruas, ao anoitecer, há tal soturnidade, há tal melancolia, e no século XXI, Cesário amigo, pouca é a melhoria" (CARVALHO, 2010, p. 100). A ironia é um dos rostos da distopia e do desencanto. 
$\mathrm{Na}$ atenta escrita de Mário de Carvalho sobressai assim a coragem e a lucidez para, enquanto inteligência crítica, diagnosticar e denunciar as várias manifestações do mal-estar de uma sociedade e de uma cultura, espetáculo que todos pressentimos, mas não somos capazes de enunciar, pelo menos deste modo. Esta literatura empenhada revela, assumidamente, uma postura ou forma de militância política e cultural, embora sem nenhuma subjugação a ditames ideológicos de partido, governo ou religião.

Um outro autor português contemporâneo, Ruben A., cujo pensamento Mário de Carvalho não desdenharia, em escritos autobiográficos de meados do séc. XX, já se referia ao "mar morto da ignorância" ${ }^{\prime \prime}$. Desse modo, diagnosticava já então, com a argúcia e o humor que lhe são reconhecidos, o peso cinzento de cultura fechada e sem consciência de limitações fundamentais. Cerca de meio século depois, Mário de Carvalho poderia aplicar a mesma expressão à cultura reinante no Portugal democrático, nos alvores do séc. XXI.

Legitimando superiormente o papel da arte, já antes escrevera Fernando Pessoa (1966, p. 30) na revista Athena, em 1924, que "o fim da arte inferior é agradar, o fim da arte superior é libertar". E acrescentamos nós, na senda de Mário de Carvalho e das suas descrições reprovadoras: libertar da barbárie cultural, da alienação da memória, do esvaziamento ético, do abastardamento da língua, enfim, do afastamento de uma riquíssima herança humanista. A grande arte liberta-nos, enfim, porque nos torna mais conscientes, mais críticos e, consequentemente, mais humanos. Mas, deixando de lado a sugerida distinção hierárquica da produção artística, cabe mesmo essa função ao escritor e ao intelectual de hoje?

\section{Atual dever dos intelectuais}

Como ilustrado, em Mário de Carvalho, estamos perante uma escrita claramente que exprime desencanto perante o colapso de uma certa concepção de cultura; sem deixar de se mostrar empenhada no retrato e na denúncia de um rumo preocupante da sociedade contemporânea que, sob a justificativa da intensidade da globalização, perde a sua memória; questiona a própria ideia de cultura (de identidades culturais e sua hibridização); e pratica um iconoclasta apagamento de valores ou padrões estéticos.

Nesse sentido, a escrita atenta, interventiva e humorada deste autor assume algumas reflexões éticas de pensadores como Edward Said, sobre o actual papel dos escritores e intelectuais. O escritor toma a iniciativa de testemunhar criticamente a so-

5 Cf. em Ruben A. (1995, p. 137), poderoso retrato surrealizante e alegórico de certo Portugal estagnado no tempo salazarista, que nem as velhas ligações culturais francesas conseguem redimir. ciedade que o cerca, dirigindo farpas satíricas e paródicas quer aos poderes instaurados - do poder político e educacional até às instituições da cultura e da literatura. Com que legitimidade o faz? Como assinalado por Said (2006, p. 153, 161, 162), ao escritor atual impõe-se "decirle la verdade al poder, dar fe de la persecución y el sufrimiento y alzar una voz disenso en los conflictos con la autoridade", 
6 Talvez possamos ver nesta função do escritor e do intelectual a atualização possível do velho tópico da "pena" e da "espada" da cultura clássica. Porém, para os mais cépticos, o mal-estar civilizacional de uma cultura globalizada coloca cada vez mais reservas ao papel do intelectual, sobretudo se comparado com tempos passados: infelizmente, sofrendo uma crise de legitimação no campo intelectual e cultural, “o escritor já não exerce a influência que tinha dantes sobre o curso dos acontecimentos, incitando as populações à rebelião, ao protesto ou à mudança do governo" (AA VV., 2002, p. 256). a partir do capital simbólico (Bourdieu) de que (ainda) é portador na esfera pública.

Neste sentido, o escritor ou o intelectual distinguem-se (ou devem) pelo pronunciamento político, sempre em favor da liberdade e da justiça, da igualdade e da cultura, ao formalizar esteticamente as aspirações dos seus concidadãos, sobretudo dos mais conscientes: "Por consiguiente, el intelectual se encuentra en la posición de hacer posible y mejorar la formulación de estas expectativas y deseos". Neste afã crítico-reflexivo de construção de uma sociedade mais justa e mais participativa, o discurso estético ou ensaístico do escritor ou do intelectual tem como nobre função a de "desenmascar y esclarecer (...), y oponer-se, desafiar y derrotar". Por outras palavras: deve desvendar silêncios e combater hipocrisias, contrariar ortodoxias e questionar poderes, defender valores e relevar a tradição cultural - em suma, apresentar narrativas e visões alternativas, pensar e incomodar as consciências, sobretudo em sociedades globalizadas, amorfas e paralisadas. Só assim o escritor e o intelectual estarão à altura do padrão formulado por Said (2006, p. 170): “(...) el hogar provisional del intelectual es la esfera de un arte exigente, resistente e intransigente al que, por desgracia, no podemos retirarnos ni acudir en busca de soluciones". ${ }^{6}$

Porém, insista-se na pergunta axial: a escrita literária e a cultura humanística podem e devem desempenhar assim um papel ativo de diagnóstico e de denúncia do estado da sociedade? Participar de modo empenhado no processo de desbarbarização da cultura, juntamente com o sistema educacional? Numa palavra, tem a literatura a função ou o poder de humanizar o homem em cada época, na construção de um utópico mundo melhor? Malgrado visões díspares, a criação literária manteve ao longo dos tempos esse desiderato ou essa promessa - educar ou formar, em variantes diversas do utile ou prodesse horacianos.

$\mathrm{Na}$ atualidade, autores como a filósofa norte-americana Martha Nussbaum (2010, p. 54), insistem na tese da função ímpar da interdisciplinar cultura humanística, na formação e educação dos cidadãos das sociedades democráticas, enquanto pessoas educadas de forma mais integral e dotadas de uma active voice e de uma correspondente critical voice, enformadas estas por uma cultura humanística que potencia a imaginação e a inovação, mas também a capacidade argumentativa e o debate crítico.

Definitivamente, talvez mais ainda que outras artes, e hoje tal como em outras épocas - sob a ameaça de uma acentuada crise da cultura logocêntrica, em favor de novas linguagens e novos media -, a literatura possui uma vocação crítica, sobretudo como voz contestatária e de oposição face a certos poderes, discursos e demagogias que determinam o rumo da sociedade, como nos lembra Antoine Compagnon (2007, p. 45): "La littérature est d'opposition: elle a le pouvoir de contester la soummission au pouvoir. Contrepouvoir, elle révèle toute l'étendue de son pouvoir lorsqu'elle est persecuté". 
Cabe, pois, à palavra literária um papel imprescindível de postura ou de consciencialização crítica, para retomarmos o citado pensamento de Adorno. Como escreveu em Educação contra a barbárie: "Quando o problema da barbárie é colocado com toda urgência e agudeza na educação (...) então me inclino a pensar que o simples fato de a questão da barbárie estar no centro da consciência provocaria por si uma mudança". (ADORNO, 1996, p. 157) A consciencialização crítica ou a função de esclarecimento ou de iluminação (que não é exclusiva da reflexão filosófica, estendendo-se às artes e, em particular, à literatura) constituiria a primeira etapa de racionalização e de consequente mobilização, contrariando a repetição de erros, o imobilismo ou a passividade (aparentemente inofensiva), próprios uma forma criminosa de barbárie, por omissão ou alheamento diante dos sintomas de ruína.

Neste sentido, opondo-se criticamente a determinado status quo vigente, a palavra literária afirma-se como uma forma de aversão a todas as modalidades de violência, de intolerância e de regressão à barbárie; como forma de ativa resistência cívica, antecâmara da necessária e urgente mobilização - pensar como etapa de preparação indispensável da intervenção prática. Numa palavra, de acordo com este ideário de Adorno, também a palavra literária pode configurar um princípio de desbarbarização.

Reescrevendo a disjunção de alguns criadores de discursos políticos e de utopias, justificadores da felicidade e da aurora dos povos, como a proclamada por Engels face à então desejada transição do capitalismo para o socialismo - socialismo ou barbárie -, poderíamos hoje repetir o repto tantas vezes pronunciado: não haverá futuro para a cultura contemporânea sem memória. No radicalismo da sua visão pessimista, Peter Sloterdijk relembra a luta perdida do legado da cultura filosófica e literária, sobretudo a partir da segunda metade de Novecentos, numa cultura assumidamente pós-humanista. No mal-estar da nova, apressada e biotecnológica sociedade atual, nas antípodas de certa concepção bucólica e pastoral, a arte, a leitura ou a "domesticação educativa" da "cultura escrita" tradicional já não têm o poder de tornar o rebanho mais humano (humanitas): "É que a cultura contemporânea é também o teatro do combate de titãs entre os impulsos domesticadores e os bestializantes, e os seus correspondentes media". (SLOTERDIJK, 2007, p. 28, 61, 64)

Contudo, apesar das fundamentadas reservas mais ou menos críticas de pensadores contemporâneos como Steiner e Sloterdijk, talvez ainda haja espaço e esperança para o papel desempenhado pela vigilância crítica da palavra literária. $\mathrm{O}$ próprio Sloterdijk, ao caracterizar a atual sociedade pós-literária e pós-humanista, explicita que não se trata do fim da literatura, mas de uma alteração muito substancial da sua relevância no espaço público, bem distinta da centralidade de outrora: “Tal não 
O mesmo António CAndido (2004, p. 22) define expressamente $o$ que entende por humanização operada pela literatura: "(...) o processo que confirma no homem aqueles traços que reputamos essenciais, como o exercício de reflexão, a aquisição do saber, a boa disposição para com o próximo, o afinamento das emoções, a capacidade de penetrar nos problemas da vida, o senso de beleza, a percepção da complexidade do mundo e dos seres, o cultivo do humor. A literatura desenvolve em nós a quota de humanidade na medida em que nos torna mais compreensivos e abertos para a natureza, a sociedade, o semelhante". significa de modo nenhum o fim da literatura, mas que esta se diferenciou como uma subcultura sui generis, e que já passaram os dias da sua sobrevalorização como portadora dos génios nacionais" (SLOTERDIJK, 2007, p. 28-29).

Em suma, a leitura e a literatura ainda podem resgatar o homem da bestialidade e de novas formas de barbárie, tal como apregoado pelo tradicional credo humanista? Sabemos a resposta desenganada deste e de outros pensadores, quanto ao potencial reformista e humanizador da literatura à pergunta retórica ainda formulada por muitos: "Quem hoje se interroga sobre o futuro da humanidade e dos meios de humanização quer saber no fundo se ainda há ainda esperança de dominar as tendências actuais para a queda do humano na selvajaria". (SLOTERDIJK, 2007, p. 31) Num breve diálogo intelectual de Mário de Carvalho, um dos interlocutores pergunta sobre o lugar das manifestações da arte: “- E lá fora, a arte continua?" Logo adiante: “- Há literatura? Há pintura, há música?». E conclui profeticamente: “- Notem: quando a arte desaparecer, e isso pode suceder dum momento para o outro, a civilização estará no fim" (CARVALHO, 2003a, p. 155-6).

Por isso, escolhendo uma via menos céptica ou radical, sentimo-nos tentados a aderir às ideias de "crentes" como Antônio Candido, nomeadamente à tese sobre o direito à literatura no mundo atual como um direito básico fundamental, um bem insubstituível ou de primeira necessidade - "uma necessidade universal imperiosa" (CANDIDO, 2004, p.16) -, porque pertencendo à categoria dos bens "que garantem a integridade espiritual" do homem. Porque, além de arte ou criação estética, a literatura distingue-se como "um instrumento poderoso de instrução e de educação", isto é, como forma peculiar de conhecimento e de humanização ${ }^{7}$, com relações ao nível dos valores e do contrato social vigente em várias épocas: "A literatura confirma e nega, propõe e denuncia, apoia e combate, fornecendo a possibilidade de vivermos dialeticamente os problemas». Por tudo isto, «Negar a fruição da literatura é mutilar a nossa humanidade. (CANDIDO, 2004, p. 17 e 28) É também esse o pensamento que subjaz à vigiliante criação literária de Mário de Carvalho. 
ticularly clear in some of his narratives, therefore problematizing, indirectly, the engaged function or nature of literary art as followed by several contemporary thinkers - from Adorno and Said to Steiner or Sloterdjk.

Keywords: barbarism of ignorance; intellectual ethics; Mário de Carvalho; cultural memory; postmodernism.

\section{REFERÊNCIAS}

AA VV. As chaves do século XXI. Lisboa: Instituto Piaget, 2002. ADORNO, Theodor W. Educação e emancipação. São Paulo: Paz e Terra, 1996.

CANDIDO, Antônio. O direito à literatura e outros ensaios. Coimbra: Angelus Novus, 2004.

CARVALHO, Mário de. Era bom que trocássemos umas ideias sobre o assunto, 5 ed., Lisboa, Caminho, 2003a 1 ed., 1995.

$2003 b$.

. Fantasia para dois coronéis e uma piscina. Lisboa: Caminho,

A arte de morrer longe. 2 ed., Lisboa: Caminho, 2010.

Identidade. Identificando. Flanando por fronteiras. In:

Representações da portugalidade, org. André Barata et alii. Lisboa: Caminho, 2011, p. 271-279.

COMPAGNON, Antoine, La Littérature, pour quoi faire?, Paris: Collège de France / Fayard, 2007

NIETZSCHE, Friederich, em O Nascimento da tragédia. São Paulo: Companhia das Letras, 1992.

NUSSBAUM, Martha, Not For Profit (Why Democracy Needs the Humanities). Princeton University Press: Princeton and Oxford, 2010. PESSOA, Fernando. Páginas de estética e de teoria literárias. Lisboa: Ática [textos estabelecidos e prefaciados por Georg Rudolf Lind e Jacinto do Prado Coelho], 1966.

RUBEN A. A Torre de Barbela. Lisboa: Assírio \& Alvim, 1995.

SAID, Edward. La función pública de los escritores e intelectuales. In: Humanismo y crítica democrática. Barcelona: Debate, p. 145-171, 2006.

SLOTERDIJK, Peter. Regras para o parque humano. Coimbra: Angelus Novus, 2007.

STEINER, George. No Castelo do Barba Azul (Algumas notas para a redefinição da cultura). Lisboa: Relógio d'Água, 1992.

STEINER, George \& SPIRE, Antoine. Barbárie da ignorância. Lisboa: Fim de Século, 2004. 